\title{
Pulmonary arterial hypertension among HIV-infected children: results of a national survey and review of the literature
}

\author{
Arnaud Grégoire L'Huillier ${ }^{1}$, Klara Maria Posfay-Barbe ${ }^{1 *}{ }^{*}$ Hiba Pictet $^{2}$ and Maurice Beghetti ${ }^{3}$ \\ 1 Pediatric Infectious Diseases Unit, Department of Pediatrics, Geneva University Hospitals, Geneva, Switzerland \\ ${ }^{2}$ Faculty of Medicine, University of Geneva, Geneva, Switzerland \\ ${ }_{3}^{3}$ Pediatric Cardiology Unit, Department of Pediatrics, Geneva University Hospitals, Geneva, Switzerland
}

Edited by:

Oswin Grollmuss, Centre Chirurgical Marie Lannelongue, France

Reviewed by:

Dunbar Ivy, University of Colorado

School of Medicine, USA

Christian Apitz, Pediatric Heart Center

Giessen, Germany

Olivier Sitbon, Université Paris-Sud,

France

\section{${ }^{*}$ Correspondence}

Klara Maria Posfay-Barbe, Pediatric

Infectious Diseases Unit, Department of Pediatrics, Geneva University

Hospitals, Rue Willy-Donzé, 6,

Geneva 14 1211, Switzerland

e-mail: klara.posfaybarbe@hcuge.ch
Since the advent of highly active anti-retroviral therapy, HIV-related mortality has decreased dramatically. As a consequence, patients are living longer, and HIV infection is becoming a chronic disease. Patients and caretakers have to deal with chronic complications of infection and treatment, such as cardiovascular diseases, which now represent an important health issue, even in the pediatric population. Prevalence of pulmonary arterial hypertension (PAH) in the adult HIV population is around $0.4-0.6 \%$, which is around 1000 - to 2500 -fold more prevalent than in the general population. In recent adult PAH registries, HIV has been identified as the fourth cause of $\mathrm{PAH}$, accounting for approximately $6-7 \%$ of cases. Therefore, regular screening is recommended in HIV-infected adults by many experts. If HIV-associated PAH is mainly reported in HIV-infected adults, pediatric cases have also been, albeit rarely, described. This scarcity may be due to a very low PAH prevalence, or due to the lack of systematic cardiovascular screening in pediatric patients. As PAH may manifest only years or decades after infection, a systematic screening should perhaps also be recommended to HIV-infected children. In this context, we retrospectively looked for PAH screening in children included in our national Swiss Mother and Child HIV cohort study. A questionnaire was sent to all pediatric infectious disease specialists taking care of HIV-infected children in the cohort. The questions tried to identify symptoms suggestive of cardiovascular risk factors and asked which screening test was performed. In the 71 HIVinfected children for which we obtained an answer, no child was known for PAH. However, only two had been screened for PAH, and the diagnosis was not confirmed. In conclusion, PAH in HIV-infected children is possibly underestimated due to lack of screening. Systematic echocardiographic evaluation should be performed in HIV-infected children.

Keywords: human immunodeficiency virus, pediatrics, pulmonary artery hypertension, screening, survey

\section{REVIEW}

\section{INTRODUCTION}

WHO estimated in 2010 that 34 millions of humans were infected with HIV, $10 \%$ being younger than 15 years old (1). In children, infection mainly happens through transmission between mother and child during the pre-, peri-, or postnatal period (through breastfeeding). The risk of infection differs according to the mode of transmission (2), and also depends on the viremia of the source patient (3). The infected person often presents an asymptomatic period lasting $5-10$ years without treatment, depending on viremia and CD4 T-cell count (4).

Since the advent of highly active anti-retroviral therapy (HAART), HIV-related mortality has decreased dramatically both in adults (5) and children (6-8). As a consequence, patients are living longer, and HIV infection is becoming a chronic disease. Patients and caretakers have to deal with chronic complications of the infection and the treatment, such as cardiovascular disease, which now represent an important health issue in this patient population (9).
Because of the lack of randomized control studies, it is difficult to differentiate the etiological role of the virus itself from the impact of HAART in pulmonary arterial hypertension (PAH), as well as other cardiovascular manifestations. PAH is a serious disease of the pulmonary arteries characterized by vascular remodeling due to dysfunctional proliferation of smooth muscle and endothelial cells (10). It leads to an increase in pulmonary vascular resistance and pulmonary arterial pressure (PAP). PAH classification was updated during the World Symposium on Pulmonary Hypertension in 2013 (11). This classification gives more importance to pediatric PAH compared to the previous Danapoint Classification (12).

Despite this, no systematic cardiovascular screening is usually suggested to HIV-infected children. To demonstrate this, we sent a questionnaire to all infectious diseases specialists taking care of HIV-infected children in Switzerland, part of the Swiss Mother and Child HIV (MoCHIV) cohort study to evaluate if they look for PAH symptoms and perform screening procedures. We will first review HIV-related 
PAH (HIV-PAH) and second describe the results of our questionnaire.

\section{EPIDEMIOLOGY}

Pulmonary arterial hypertension was described in HIV-infected patients for the first time in 1987 (13). Since then, HIV has been identified as one of the associated forms of $\mathrm{PAH}$, accounting for approximately $6-8 \%$ of cases (14-17). However, because of the high HIV prevalence worldwide and the poor screening, HIV-PAH may be an important unrecognized cause of PAH. Even if confounding factors, such as drug use and co-infection with hepatitis $\mathrm{C}$ virus (HCV) have been reported (18), more than $80 \%$ of PAH cases in the HIV population are directly related to HIV and/or its treatment $(19,20)$.

Pulmonary arterial hypertension is defined as a resting PAP $>25 \mathrm{mmHg}$, associated with a pulmonary arterial occlusion pressure (PAOP) $\leq 15 \mathrm{mmHg}$ (21). HIV-PAH diagnosis can only be confirmed once all other possible etiologies have been excluded.

Diagnosis relies on clinical symptoms, such as fatigue and dyspnea, as well as clinical findings, such as an increase in the pulmonary component of the second heart sound, a tricuspid regurgitation murmur or a right fourth heart sound, and signs of right heart failure. Chest X-rays may show cardiomegaly and pulmonary arteries enlargement, and the electrocardiogram shows right ventricular hypertrophy with right axis deviation. When PAH is suspected, echocardiography is the most useful diagnostic tool (22). Confirmation with right heart catheterization (RHC) is the gold standard. Some authors recently proposed a diagnosis algorithm $(23,24)$.

Prevalence of HIV-PAH is around $0.2-0.6 \%(20,23,25-30)$, which is 1000 - to 2500 -fold more prevalent than in the general population $(20,23)$. However, as PAH may present with very scarce symptoms and no systematic screening is usually offered in the HIV-infected population, these results are probably underestimated. Most previously mentioned studies included only symptomatic patients. When all HIV-infected patients of a cohort are included and/or when using only echocardiography without RHC confirmation, HIV-PAH prevalence reaches $2.5-10 \%(18,29,31-$ 33). Compared to patients with HIV-PAH diagnosed using RHC, mean PAP values were $20 \mathrm{mmHg}$ higher when diagnosis was established only with echocardiography, suggesting that echocardiography overestimates PAP (22). Hsue et al. described pathological PAP by echocardiography in $35 \%$ of their HIV-infected cohort (14). In a recent study, HIV-PAH prevalence was $57 \%$, but only patients with tricuspid regurgitation were included and methods to calculate PAP were different (34).

\section{PHYSIOPATHOLOGY AND HISTOLOGICAL FEATURES}

HIV-related PAH physiopathology is not completely understood, is probably multifactorial, and includes genetic factors. It is hypothesized that HIV acts as a trigger, maintaining chronic inflammation and immune activation. Histological features, which closely resemble those seen in idiopathic $\mathrm{PAH}$, show in most cases a pulmonary arteriopathy with so-called "plexiform lesions" associated with concentric laminar intimal fibrosis, medial hyperplasia, and white cells. They suggest chronic inflammation $(13,19,20$, $28,35-38)$. Occasionally, plexiform lesions are lacking, possibly because it is an earlier stage of the disease (39). More rarely, thrombotic arteriopathy of the small vessels has been described (40). As simian immunodeficiency virus (SIV) infection of macaques shares many characteristics with HIV infection, these animals have been used as non-human primate model of HIV: plexiform lesions were only recovered among macaques infected with SHIV, a viral construct containing the HIV Nef protein in an SIV backbone, but not among SIV alone-infected macaques (41). In contrast, in another animal study, all SIV and SHIV macaques had elevated PAP associated with histological changes consisting mostly of intimal and medial hyperplasia. PAP values were higher in SIV and SHIV macaques than in healthy macaques, and PAP increased as early as 3 months after SIV infection (42).

HIV was never detected - to our knowledge - in the pulmonary endothelial cell using different techniques, such as immunohistochemistry, HIV-DNA hybridization, electron microscopy, or PCR. The absence of virus in endothelial cells, but its presence in alveolar macrophages, suggests an indirect action through mediator release rather than a direct endothelial infection $(39,43-45)$. Absence of virus in endothelial cells has also been described in SIV (46).

Endothelial dysfunction in PAH is characterized by a reduced production of vasodilatators prostacyclin and nitric oxide (NO) and an increased production of endothelin-1 (ET-1) (47), a potent vasoconstrictor: its importance in idiopathic $\mathrm{PAH}$ pathology has been widely studied (48). Pellicelli et al. demonstrated increased levels of ET-1, IL-6, and TNF-alpha among HIV-PAH patients compared to HIV-infected patients without PAH. They also showed that plasmatic concentrations of ET- 1 and IL- 6 were correlated to severity of HIV-PAH (49).

The role of viral proteins has also been studied. Despite the absence of virus in endothelial cells, HIV envelope protein Gp120 has been shown to be toxic in vitro by inducing pulmonary endothelial cells apoptosis and time- and dose-dependent increase in ET-1 $(50,51)$. Moreover, Gp120 activates T lymphocytes (52) and increases TNF-alpha production (51), which sustains inflammation and may play a subsequent role in HIV-PAH development. Another recent study has shown that Gp120 stimulates arterial smooth muscle cells to a express tissue factor, initiating the coagulation cascade (53). Other HIV viral proteins, such as Nef and Tat, lead to chronic inflammation and endothelial dysfunction and may play a role in HIV-PAH pathogenesis. Nef has been shown to increase monocyte migration, enhancing local inflammation (54). Moreover, Nef was detected in lungs endothelial cells from HIV-PAH patients, but not among healthy or idiopathic $\mathrm{PAH}$ patients, suggesting that while the virus does not enter endothelium, it is possible that secreted viral proteins do (41). A group recently showed that the risk of HIV-PAH was related to the number of Nef mutations and that some polymorphisms mapped to Nef functional domains were overrepresented among HIV-PAH patients $(55,56)$.

Tat is another viral protein secreted by HIV-infected cells, which stimulates endothelial cells, enhancing vascular permeability via IL-6 (57). It has been suggested that Tat induces chronic inflammation and endothelial dysfunction (58). Once the endothelium is damaged, exposure of vascular smooth muscle cells to viral proteins such as Tat down regulates antiangiogenic factor BMPR: 
this promotes vascular smooth muscle cells proliferation and hypertrophy (59).

Similarly, HIV-1 proteins expression increased pulmonary vascular resistance among rats exposed to chronic hypoxia compared to wild-type rats $(60)$.

Levels of asymmetric dimethylarginine (ADMA), an endothelial NO synthase inhibitor, are increased during HIV infection because of sustained inflammation. This may contribute to endothelial dysfunction, as ADMA levels are correlated with PAP in HIV-infected patients (61). Platelet-derived growth factor (PDGF) can induce proliferation and migration of smooth cells: Humbert et al. found that PDGF expression was increased in perivascular areas of the lungs of HIV-PAH patients (43). Similarly, increased vascular endothelial growth factor (VEGF) expression in HIV-infected patients may alter vascular permeability and induce endothelial cells (62). As only a small proportion of patients develop HIV-PAH, a genetic predisposition is assumed, such as the reported association between HIV-PAH and HLA DR6 and DR52 alleles (63). Despite being identified in 70\% of familial PAH and $20 \%$ of idiopathic PAH, no BMPR-2 mutation has been identified among HIV-PAH patients (25).

Other factors may contribute to HIV-PAH pathophysiology. $\mathrm{HCV}$ infection or drug use are independent etiologies of $\mathrm{PAH}$; however, as they are more frequent among HIV-infected patients, they may act as confounding factors $(18,20)$. Cool et al. showed the presence of human herpes virus- 8 (HHV-8) in lung lesions of patients with idiopathic PAH (64). This was not confirmed in other studies on idiopathic PAH patients (65) and in HIVPAH patients, despite their immunosuppression $(14,66)$. Immune restoration in mice infected by Pneumocystis jirovecii has been shown to increase the risk of persistent PAH. However, the persistence of PAH after treatment suggests that chronic inflammation is the most important factor rather than acute infection itself (67).

\section{CLINICAL PRESENTATION}

Clinically, symptoms of HIV-PAH are similar to idiopathic PAH. Early HIV-PAH may be misdiagnosed because of non-specific symptoms, such as exercise intolerance, progressive dyspnea (85\%), edema (30\%), and non-productive cough (19\%) (19). With the progression of the disease, signs of right ventricular dysfunction appear. Compared to idiopathic $\mathrm{PAH}$, patients reported in the literature are usually younger (mean age 33 years) (19) and less symptomatic $(35,68)$. Males are proportionally more affected (male: female ratio 1.5:1 compared to 1:1.7 in idiopathic $\mathrm{PAH}$ ), reflecting the prevalence of the HIV population (19). Moreover, time between symptoms and diagnosis is generally shorter than in idiopathic PAH: possibly a consequence of closer follow-up (25).

HIV-related PAH carries a poor prognosis: mortality is mainly due to PAH rather than to HIV complications: $\mathrm{PAH}$ is therefore a predictor of mortality by itself $(20,25,26,68)$. Initial studies reported a median survival between 0.5 and 2.7 years $(19,27)$, and only $21-46 \%$ median survival at 3 years $(19,25-27)$. Earlier studies reported a faster progression (35) and a shorter survival with HIV-PAH compared to idiopathic PAH $(20,35)$. This could be explained by a more prevalent and severe ventricular systolic dysfunction among HIV-PAH patients compared to patients with PAH of other etiologies (69). More recent studies have shown a slightly improved median survival with $66-86 \%$ at 3 years (17, $70,71)$. As many deaths in these recent studies were unrelated to PAH, one may suppose a decrease in HIV-PAH-related death (71). Survival significantly decreases with an increase of NYHA stages; therefore, a clinical marker of HIV-PAH progression (25, 68 ), would be crucial to identify patients in the early, scarcely symptomatic phase of the disease.

The relationship between the severity of HIV and PAH is subject to debate. HIV-PAH occurs at all stages of HIV infection. Most authors could not show an association between HIV-PAH and low CD4 T cell count $(19,20,23,27,28,34,68)$, even if the proportion of patients with CD4 count $<200 / \mathrm{mm}^{3}$ was higher among HIVPAH patients in one study (23). On the other hand, other groups described an increased survival rate with increasing CD4 counts $(17,25,26)$.

Regarding viremia, several studies could not find an association with HIV-PAH $(23,34,68)$ but others described an increased survival with lower viremia $(17,71)$. Finally, in one study, viremia was higher among HIV-PAH patients than among HIV patients without PAH (18). To date, there are no sufficient data to confirm a protective role of HIV control through HAART on HIV-PAH's incidence and progression.

\section{TREATMENT OF HIV-PAH}

Because survival is related to NYHA stage, early diagnosis and treatment are paramount $(25,68)$. There are no current validated guidelines and HIV-PAH treatment is still controversial because of the lack of randomized studies.

\section{Non-specific treatment}

Oxygen reduces hypoxia-induced pulmonary vasoconstriction, whereas diuretics reduce right ventricular preload, and digoxin increases cardiac output. Oral anticoagulation reduces the possible thrombotic component of PAH (72), but its use for HIVPAH is often limited due to concomitant thrombocytopenia and hepatopathy. Calcium channel blockers (CCB) use has been disappointing in adult HIV-PAH because almost all patients are not responders to acute vasoreactivity testing, it lacks a sustained vasodilator effect and has important side-effects (26), possibly related to interactions with HAART (73). Given that a positive acute vasoreactivity response to $\mathrm{CCB}$ is more frequent in children than adults and that there is no pediatric data concerning CCB use in HIV-PAH, these medications should be considered in selected cases, but vasoreactivity is not common in HIV-PAH.

\section{Specific treatment}

Prostacyclin analogs can be administered by IV infusion, inhalation, or subcutaneously.

Epoprostenol, the intravenous form of a prostacyclin ana$\log$, has been shown to induce clinical $(25,74)$ and hemodynamic improvement $(25,35,74)$, especially when combined to HAART (25). Epoprostenol has been shown to increase survival (25). Its administration mode requires the use of a central venous catheter, which is linked with risks of infection and of misuse in drug abusers. Inhaled iloprost also showed hemodynamic $(27,75,76)$ and clinical $(75,76)$ improvement, 
albeit not statistically significant. Subcutaneous treprostinil increases hemodynamic and clinical parameters (77) in HIVPAH patients.

Sildenafil, a phosphodiesterase inhibitor type 5, is the most frequently used medication in idiopathic PAH. In HIV-PAH, its use is limited because of its interaction with protease inhibitors (PIs), through the 3A4 P450 cytochrome pathway (78-80). However, in case reports of patients with HIV-PAH, it showed clinical and hemodynamic improvement (81-83).

Bosentan, an oral dual endothelin receptor antagonist, acts by inhibiting the potent vasoconstricting properties of endothelin. Bosentan has been shown to induce a clinical and hemodynamic improvement among HIV-infected patients $(26,71,84,85)$. Some patients even normalized their hemodynamic values during treatment (71). In 2012, Tcherakian et al. reported two cases of sustained and completely reversible HIV-PAH with bosentan treatment, persisting after drug discontinuation (86). Bosentan is a moderate Cytochrome P450 3A4 and 2C9 inducer, therefore simultaneous administration of anti-retroviral drugs should be performed with caution (87).

A treatment algorithm was recently proposed for HIVPAH (88).

\section{ROLE OF HAART IN HIV-PAH}

The role of HAART in PAH is unclear. As chronic inflammation probably contributes to HIV-PAH pathophysiology, one may suspect a beneficial effect of HAART on HIV-PAH by reducing inflammation. In rats, PIs reverse or decrease $\mathrm{PAH}$ progression by reducing remodeling and smooth muscle cell proliferation (89). In humans, some authors showed no change in the frequency or severity of PAH since HAART was introduced, or in patients treated with HAART $(17,18,23,26)$, whereas others described a decrease of PAH incidence $(27,90)$ associated with a decline in HIV-PAH-related mortality $(25,27,71)$. Among patients with HIV-PAH, clinical improvement was observed, especially when associated to PAH medications $(17,85)$. In a similar fashion, hemodynamics improved with HAART whether or not associated to PAH medication $(26,27,85,91)$. It is possible that PIs may be the most beneficial (27).

On the other hand, other studies have shown a deleterious effect of HAART on HIV-PAH, possibly secondary to PI-induced endothelial dysfunction (92). In vitro studies have demonstrated that anti-retrovirals, especially PIs, increased ET1 production, followed by endothelial and vascular smooth muscle cell proliferation (93). Among rats, administration of AZT and PIs was associated to endothelial dysfunction and an increase in ET-1 production (94). In humans, some authors describe stable HIV-PAH after HAART interruption (95), while others describe an increased incidence with HAART compared to ART $(96,97)$ or an accelerated HIV-PAH evolution (44). Reinsch et al. reported an increased echocardiographically proven HIV-PAH prevalence among patients treated with HAART compared to naïve patients (31). Another human study associated ritonavir-boosted PIs and abacavir with HIVPAH (34).

In general, HIV-PAH prevalence has not changed significantly since HAART was introduced. This may suggest that antiviral drugs have a little effect on sites where the virus affects vascular cells. However, a protective effect of HAART on survival and incidence may explain a stable prevalence, as patients are now living longer. In clinical practice, since the Opravil et al. study showing an improvement of the pressure gradient when the patients were treated, experts recommend to introduce HAART at the time of HIV-PAH diagnosis, regardless of CD4 T-cell counts (26).

\section{PEDIATRIC DATA}

While HIV-PAH mainly concerns HIV-infected adults, pediatric cases have also been described $(63,83,98-104)$, the youngest being between 1 and 2 years old $(83,102)$. Apart from HIV infection, few of these children also have other $\mathrm{PAH}$ predisposing factors, such as hemophilia $(99,101)$. The youngest patient is an HIV-infected very-low birth-weight infant, which presented with neonatal PAH: his condition resolved with HAART treatment but confounding factors, such as persistent ductus arteriosus, prolonged mechanical ventilation, extreme prematurity, systemic infection, and persistent pulmonary hypertension of the newborn, may have contributed to the disease (105). The causality is therefore uncertain. In a cohort of pediatric $\mathrm{PAH}$ patients in the Netherlands, $1 \%$ of cases were infected with HIV (98). In vertically HIV-infected children in Thailand, more than $40 \%$ presented echocardiographic criteria for HIV-PAH, but in more than half of the cases, this could be explained by lymphoid interstitial pneumonia (106). More recently, Ferrand et al. diagnosed HIV-PAH by echocardiography in $7 \%$ of vertically infected adolescents (aged 10-19 years) from Zimbabwe (107). Cunha et al. described an echocardiographic prevalence of HIV-PAH in $4.4 \%$ of a Brazilian children cohort younger than 13 years (108). Two studies in Thailand and Zimbabwe including only symptomatic HIV-infected toddlers have described an HIV-PAH prevalence of $48-75 \%(109,110)$. The prevalence of echocardiographic HIV$\mathrm{PAH}$ among children is similar or even higher than in adult reports using only echocardiography as a diagnostic tool. This high prevalence among HIV-infected children in Asia, Africa, and South America may be explained by vertical transmission. A delayed HIV diagnosis such as described in Ferrand et al. (median age at diagnosis 12 years) may also have contributed to the high HIV-PAH prevalence (107). Finally, confounding factors, such as high prevalence of parasitic diseases, chronic hepatitis $\mathrm{B}$ and $\mathrm{C}$ infection, and high seroprevalence of $\mathrm{HHV}-8$ could have played a role.

In a recent registry study of more than 360 children in 19 countries - including Switzerland - with confirmed $\mathrm{PAH}$, there was no HIV-infected child (111). Similarly, there was no HIV-infected patient in another registry study including more than 200 children with PAH (112). This may be due to the fact that no systematic screening is performed in the HIV-infected population but also to a selection bias of both registries and their participating centers as almost all patients were symptomatic.

\section{WHAT IS DONE IN SWITZERLAND?}

To demonstrate a correlation between HIV and PAH in HIVinfected children, we retrospectively analyzed cardiovascular and, in particular, PAH screening of children in the Swiss MoCHIV cohort study. 
Questionnaire on the screening of pulmonary arterial hypertension (PAH) in a cohorte of HIV infected children

Each form corresponds to a patient with $\mathrm{HIV}$

Date of birth

Hospital Center

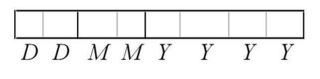

$$
\begin{aligned}
& \hline \text { GE: Genève, LS: Lausanne, ZH: Zurich, } \\
& \text { BS: Basel; SG: St-Gall, BE: Bern }
\end{aligned}
$$

1) Type of current antiretroviral treatment

$$
\text { NRTI } \square \text { NNRTI } \square \quad \text { IP }
$$

2) Was there a screening of PAH?

3) Is the child affected by PAH?

a) At what age the first symptoms have been observed?

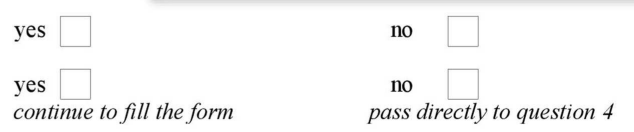

b) What was the clinical presentation?

$\begin{array}{lll}\text { Dyspnoea } & \text { yes } \square \\ \text { Hemoptysis } & \text { yes } \square & \text { no } \square \\ \text { Chest pain } & \text { yes } \square & \text { no } \square \\ \text { Dizziness } & \text { yes } \square & \text { no } \\ \text { Syncope } & \text { yes } \square & \text { no }\end{array}$

c) Date of diagnosis

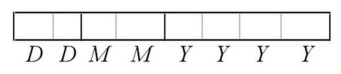

d) Which additional exams have been performed?

$\begin{array}{ll}\text { ECG } & \text { yes } \square \text { no } \\ \text { Chest radiography } & \text { yes } \square \text { no } \\ \text { Echocardiography } & \text { yes } \square \text { no } \\ \text { Scintigraphy } & \text { yes } \square \text { no }\end{array}$

Pedal edema

Increased intensity of P2

Palpable P2

A right ventricular lift

Pulmonic ejection sound

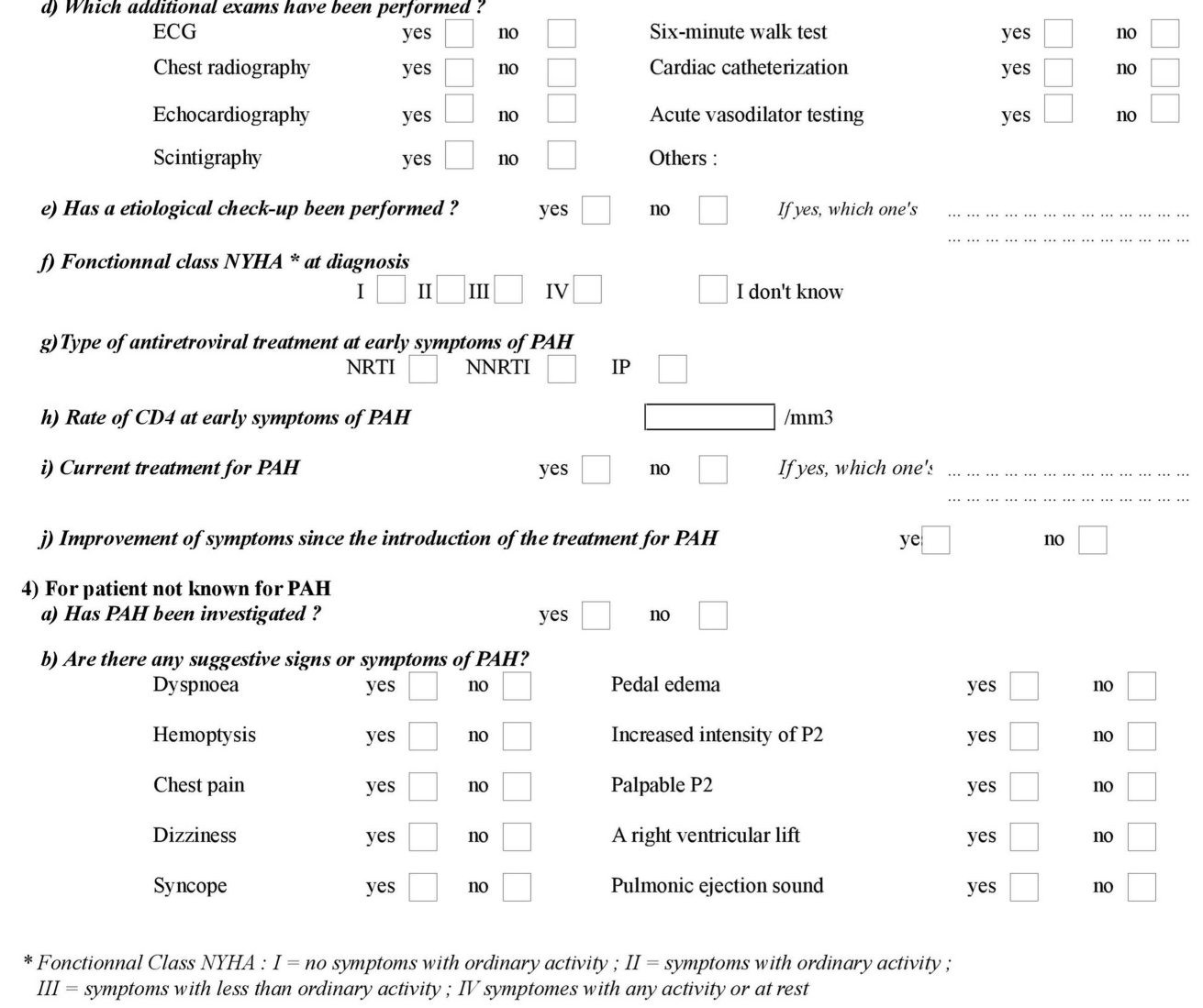

Thank you for returning the forms before the 1/04/2013 to the following address : Prof M. Beghetti, Hôpital des enfants. 6 rue Willv-Donzé. 1211 Genève 14

Thank you for your collaboration. For any questions, please contact Hiba Khiari 076-4257334 hibakhiari@gmail.com 
The MoCHIV Cohort Study is a merger of the former Neonatal HIV Study and the Swiss HIV and Pregnancy Study. Initially, the main goal was to collect a maximum of data in children born to HIV-infected mothers and HIV-infected children to gain epidemiological information and to study vertical transmission and natural history of disease. In 1998, a merged project was built named The Swiss MoCHIV Study. In 2004, a permanent link was established between the Swiss HIV Cohort Study (SHCS) and MoCHIV. Thus, longitudinal data in women included in both cohorts became available for research, making MoCHIV a very unique mother-child cohort. All mothers and children are given a cohort number, which is then used to collect data in both cohorts anonymously. Women and children are followed according to good clinical practices, as defined by the respective guidelines for adults, pregnant women, and children. These have been regularly adjusted according to growing knowledge.

It is estimated that approximately $75 \%$ of HIV-infected children living in Switzerland are part of MoCHIV. All Swiss pediatric infectious disease experts following HIV-infected children in the cohort received a person-specific questionnaire. The questions concerned symptoms suggestive of PAH and which cardiovascular screening was performed. In addition, questions concerning HIV status (CD4 T-cell count, viremia, HAART treatment or not) were recorded (Figure 1).

Among the 83 children currently included in the MoCHIV cohort study, the questionnaire was retrieved for $71(86 \%)$ children. As suspected, no child of the MoCHIV cohort was known for PAH. Only two children (3\%) had been screened for $\mathrm{PAH}$, one because of thoracic pain and one because of dizziness, but diagnosis was not confirmed. Echocardiographic studies have reported higher prevalence of PAH (106-110). It is therefore possible that HIV-PAH is under-diagnosed in Switzerland as well because systematic screening is not performed. Only symptomatic cases would be (or will be) detected. Alternatively, it is also possible that other cofactors are involved and explain the higher prevalence in other countries.

\section{CONCLUSION}

Increased PAH risk in HIV-infected children, due to HIV infection and/or anti-retroviral treatment, creates new challenges and has serious implications for the quality of life and the survival of this population. However, despite a clearly increased risk, $\mathrm{PAH}$ detection is neglected in HIV-infected children. The true impact of PAH can only be appreciated after years or decades because of its silent and slow progression. Survival among HIV-infected children will probably continue to increase with more potent treatment options. As demonstrated in several studies, the prevalence of echocardiographic signs of increased PAP despite being below PAH definition level is more frequent than expected, even in children. Therefore, a systematic PAH screening should be proposed in this at-risk population (113-117). An echocardiography should be performed in all HIV-infected children at least once. However, a regular echocardiographic follow-up would be even more helpful, despite its cost, because there is a better outcome when diagnosis is early. RHC should be offered to all patients with abnormal echocardiographic findings. This has been successfully done in adult patients with sickle cell disease or scleroderma, another pathology associated with PAH $(118,119)$. Moreover, because only a proportion of HIV-infected patients develop HIV-PAH, finding biomarkers predicting HIV-PAH would be essential for the future.

\section{ACKNOWLEDGMENTS}

The authors acknowledge all members of the MoCHIV cohort study who answered our questionnaire, especially Jean-Jacques Cheseaux, Claire-Anne Wyler, David Nadal, Christian Kahlert, Andrea Duppenthaler, and Christoph Rudin.

\section{REFERENCES}

1. WHO. Progress Report 2011: Global HIV/AIDS Response. Geneva: World Health Organisation (2011). p. 1-233.

2. Hladik F, McElrath MJ. Setting the stage: host invasion by HIV. Nat Rev Immunol (2008) 8(6):447-57. doi:10.1038/nri2302

3. Cohen MS, Shaw GM, McMichael AJ, Haynes BF. Acute HIV-1 infection. N Engl J Med (2011) 364(20):1943-54. doi:10.1056/NEJMra1011874

4. Bacchetti P, Moss AR. Incubation period of AIDS in San Francisco. Nature (1989) 338(6212):251-3. doi:10.1038/338251a0

5. Palella FJ Jr, Delaney KM, Moorman AC, Loveless MO, Fuhrer J, Satten GA, et al. Declining morbidity and mortality among patients with advanced human immunodeficiency virus infection. HIV outpatient study investigators. $N$ Engl J Med (1998) 338(13):853-60. doi:10.1056/NEJM199803263381301

6. van Rossum AM, Fraaij PL, de Groot R. Efficacy of highly active antiretroviral therapy in HIV-1 infected children. Lancet Infect Dis (2002) 2(2):93-102. doi:10.1016/S1473-3099(02)00183-4

7. Gortmaker SL, Hughes M, Cervia J, Brady M, Johnson GM, Seage GR III, et al. Effect of combination therapy including protease inhibitors on mortality among children and adolescents infected with HIV-1. N Engl J Med (2001) 345(21):1522-8. doi:10.1056/NEJMoa011157

8. Lohse N, Hansen AB, Pedersen G, Kronborg G, Gerstoft J, Sorensen HT, et al. Survival of persons with and without HIV infection in Denmark, 19952005. Ann Intern Med (2007) 146(2):87-95. doi:10.7326/0003-4819-146-2200701160-00003

9. Hasse B, Ledergerber B, Furrer H, Battegay M, Hirschel B, Cavassini M, et al. Morbidity and aging in HIV-infected persons: the Swiss HIV cohort study. Clin Infect Dis (2011) 53(11):1130-9. doi:10.1093/cid/cir626

10. Archer S, Rich S. Primary pulmonary hypertension: a vascular biology and translational research "work in progress". Circulation (2000) 102(22):2781-91. doi:10.1161/01.CIR.102.22.2781

11. Simonneau G, Gatzoulis MA, Adatia I, Celermajer D, Denton C, Ghofrani A, et al. Updated clinical classification of pulmonary hypertension. J Am Coll Cardiol (2013) 62(25 Suppl):D34-41. doi:10.1016/j.jacc.2013.10.029

12. Ivy DD, Abman SH, Barst RJ, Berger RM, Bonnet D, Fleming TR, et al. Pediatric pulmonary hypertension. J Am Coll Cardiol (2013) 62(25 Suppl):D117-26. doi:10.1016/j.jacc.2013.10.028

13. Kim KK, Factor SM. Membranoproliferative glomerulonephritis and plexogenic pulmonary arteriopathy in a homosexual man with acquired immunodeficiency syndrome. Hum Pathol (1987) 18(12):1293-6. doi:10.1016/S00468177(87)80417-3

14. Hsue PY, Deeks SG, Farah HH, Palav S, Ahmed SY, Schnell A, et al. Role of HIV and human herpesvirus- 8 infection in pulmonary arterial hypertension. AIDS (2008) 22(7):825-33. doi:10.1097/QAD.0b013e3282f7cd42

15. Humbert M, Sitbon O, Chaouat A, Bertocchi M, Habib G, Gressin V, et al. Pulmonary arterial hypertension in France: results from a national registry. Am J Respir Crit Care Med (2006) 173(9):1023-30. doi:10.1164/rccm.2005101668OC

16. Simonneau G, Galie N, Rubin LJ, Langleben D, Seeger W, Domenighetti G, et al. Clinical classification of pulmonary hypertension. J Am Coll Cardiol (2004) 43(12 Suppl S):5S-12S. doi:10.1016/j.jacc.2004.02.037

17. Degano B, Guillaume M, Savale L, Montani D, Jais X, Yaici A, et al. HIVassociated pulmonary arterial hypertension: survival and prognostic factors in the modern therapeutic era. AIDS (2010) 24(1):67-75. doi:10.1097/QAD. 0b013e328331c65e

18. Quezada M, Martin-Carbonero L, Soriano V, Vispo E, Valencia E, Moreno $\mathrm{V}$, et al. Prevalence and risk factors associated with pulmonary hypertension 
in HIV-infected patients on regular follow-up. AIDS (2012) 26(11):1387-92. doi:10.1097/QAD.0b013e328354f5a1

19. Mehta NJ, Khan IA, Mehta RN, Sepkowitz DA. HIV-related pulmonary hypertension: analytic review of 131 cases. Chest (2000) 118(4):1133-41. doi:10.1378/chest.118.4.1133

20. Mesa RA, Edell ES, Dunn WF, Edwards WD. Human immunodeficiency virus infection and pulmonary hypertension: two new cases and a review of 86 reported cases. Mayo Clin Proc (1998) 73(1):37-45. doi:10.1016/S00256196(11)63616-1

21. Hoeper MM, Bogaard HJ, Condliffe R, Frantz R, Khanna D, Kurzyna M, et al. Definitions and diagnosis of pulmonary hypertension. JAm Coll Cardiol (2013) 62(25 Suppl):D42-50. doi:10.1016/j.jacc.2013.10.032

22. Janda S, Quon BS, Swiston J. HIV and pulmonary arterial hypertension: a systematic review. HIV Med (2010) 11(10):620-34. doi:10.1111/j.1468-1293. 2010.00829.x

23. Sitbon O, Lascoux-Combe C, Delfraissy JF, Yeni PG, Raffi F, De Zuttere D, et al. Prevalence of HIV-related pulmonary arterial hypertension in the current antiretroviral therapy era. Am J Respir Crit Care Med (2008) 177(1):108-13. doi:10.1164/rccm.200704-541OC

24. Cicalini S, Almodovar S, Grilli E, Flores S. Pulmonary hypertension and human immunodeficiency virus infection: epidemiology, pathogenesis, and clinical approach. Clin Microbiol Infect (2011) 17(1):25-33. doi:10.1111/j.1469-0691. 2010.03286.x

25. Nunes H, Humbert M, Sitbon O, Morse JH, Deng Z, Knowles JA, et al. Prognostic factors for survival in human immunodeficiency virus-associated pulmonary arterial hypertension. Am J Respir Crit Care Med (2003) 167(10):1433-9. doi:10.1164/rccm.200204-3300C

26. Opravil M, Pechere M, Speich R, Joller-Jemelka HI, Jenni R, Russi EW, et al. HIV-associated primary pulmonary hypertension. A case control study. Swiss HIV cohort study. Am J Respir Crit Care Med (1997) 155(3):990-5. doi:10.1164/ajrccm.155.3.9117037

27. Zuber JP, Calmy A, Evison JM, Hasse B, Schiffer V, Wagels T, et al. Pulmonary arterial hypertension related to HIV infection: improved hemodynamics and survival associated with antiretroviral therapy. Clin Infect Dis (2004) 38(8):1178-85. doi:10.1086/383037

28. Speich R, Jenni R, Opravil M, Pfab M, Russi EW. Primary pulmonary hypertension in HIV infection. Chest (1991) 100(5):1268-71. doi:10.1378/chest.100. 5.1268

29. Ten Freyhaus H, Vogel D, Lehmann C, Kummerle T, Wyen C, Fatkenheuer G, et al. Echocardiographic screening for pulmonary arterial hypertension in HIV-positive patients. Infection (2014) 42(4):737-41. doi:10.1007/s15010014-0610-8

30. Petrosillo N, Chinello P, Cicalini S. Pulmonary hypertension in individuals with HIV infection. AIDS (2006) 20(16):2128-9. doi:10.1097/01.aids.0000247569. 03504.8b

31. Reinsch N, Buhr C, Krings P, Kaelsch H, Kahlert P, Konorza T, et al. Effect of gender and highly active antiretroviral therapy on HIV-related pulmonary arterial hypertension: results of the HIV-HEART study. HIV Med (2008) 9(7):550-6. doi:10.1111/j.1468-1293.2008.00602.x

32. Niakara A, Drabo YJ, Kambire Y, Nebie LV, Kabore NJ, Simon F. [Cardiovascular diseases and HIV infection: study of 79 cases at the national hospital of Ouagadougou (Burkina Faso)]. Bull Soc Pathol Exot (2002) 95(1):23-6.

33. Isasti G, Moreno T, Perez I, Cabrera F, Palacios R, Santos J. High prevalence of pulmonary arterial hypertension in a cohort of asymptomatic HIV-infected patients. AIDS Res Hum Retroviruses (2013) 29(2):231-4. doi:10.1089/AID. 2012.0166

34. Mondy KE, Gottdiener J, Overton ET, Henry K, Bush T, Conley L, et al. High prevalence of echocardiographic abnormalities among HIV-infected persons in the era of highly active antiretroviral therapy. Clin Infect Dis (2011) 52(3):378-86. doi:10.1093/cid/ciq066

35. Petitpretz P, Brenot F, Azarian R, Parent F, Rain B, Herve P, et al. Pulmonary hypertension in patients with human immunodeficiency virus infection. Comparison with primary pulmonary hypertension. Circulation (1994) 89(6):2722-7.

36. Polos PG, Wolfe D, Harley RA, Strange C, Sahn SA. Pulmonary hypertension and human immunodeficiency virus infection. Two reports and a review of the literature. Chest (1992) 101(2):474-8. doi:10.1378/chest.101.2.474

37. Coplan NL, Shimony RY, Ioachim HL, Wilentz JR, Posner DH, Lipschitz A, et al. Primary pulmonary hypertension associated with human immunodeficiency viral infection. Am J Med (1990) 89(1):96-9. doi:10.1016/0002-9343(90) 90105-M

38. Cool CD, Kennedy D, Voelkel NF, Tuder RM. Pathogenesis and evolution of plexiform lesions in pulmonary hypertension associated with scleroderma and human immunodeficiency virus infection. Hum Pathol (1997) 28(4):434-42. doi:10.1016/S0046-8177(97)90032-0

39. Mette SA, Palevsky HI, Pietra GG, Williams TM, Bruder E, Prestipino AJ, et al. Primary pulmonary hypertension in association with human immunodeficiency virus infection. A possible viral etiology for some forms of hypertensive pulmonary arteriopathy. Am Rev Respir Dis (1992) 145(5):1196-200. doi:10.1164/ajrccm/145.5.1196

40. Heron E, Laaban JP, Capron F, Quieffin J, Brechot JM, Rochemaure J. Thrombotic primary pulmonary hypertension in an HIV+ patient. Eur Heart J (1994) 15(3):394-6.

41. Marecki JC, Cool CD, Parr JE, Beckey VE, Luciw PA, Tarantal AF, et al. HIV-1 Nef is associated with complex pulmonary vascular lesions in SHIVnef-infected macaques. Am J Respir Crit Care Med (2006) 174(4):437-45. doi:10.1164/rccm.200601-005OC

42. George MP, Champion HC, Simon M, Guyach S, Tarantelli R, Kling HM, et al. Physiologic changes in a nonhuman primate model of HIV-associated pulmonary arterial hypertension. Am J Respir Cell Mol Biol (2013) 48(3):374-81. doi:10.1165/rcmb.2011-0434OC

43. Humbert M, Monti G, Fartoukh M, Magnan A, Brenot F, Rain B, et al. Plateletderived growth factor expression in primary pulmonary hypertension: comparison of HIV seropositive and HIV seronegative patients. Eur Respir J (1998) 11(3):554-9.

44. Pellicelli AM, Palmieri F, D’Ambrosio C, Rianda A, Boumis E, Girardi E, et al. Role of human immunodeficiency virus in primary pulmonary hypertension - case reports. Angiology (1998) 49(12):1005-11. doi:10.1177/ 000331979804901206

45. Conly J, Hilsden R, Deneer H, Etches I, Moyana T. Primary pulmonary hypertension and human immunodeficiency virus infection. Can J Infect Dis (1997) 8(5):290-3.

46. Chalifoux LV, Simon MA, Pauley DR, MacKey JJ, Wyand MS, Ringler DJ. Arteriopathy in macaques infected with simian immunodeficiency virus. Lab Invest (1992) 67(3):338-49.

47. Humbert M, Morrell NW, Archer SL, Stenmark KR, MacLean MR, Lang IM, et al. Cellular and molecular pathobiology of pulmonary arterial hypertension. J Am Coll Cardiol (2004) 43(12 Suppl S):13S-24S. doi:10.1016/j.jacc.2004.02. 029

48. Giaid A, Yanagisawa M, Langleben D, Michel RP, Levy R, Shennib H, et al. Expression of endothelin-1 in the lungs of patients with pulmonary hypertension. N Engl J Med (1993) 328(24):1732-9. doi:10.1056/ NEJM199306173282402

49. Pellicelli AM, D’Ambrosio C, Vizza CD, Borgia MC, Tanzi P, Pino P, et al. HIVrelated pulmonary hypertension. From pathogenesis to clinical aspects. Acto Cardiol (2004) 59(3):323-30. doi:10.2143/AC.59.3.2005190

50. Kanmogne GD, Primeaux C, Grammas P. Induction of apoptosis and endothelin-1 secretion in primary human lung endothelial cells by HIV1 gp120 proteins. Biochem Biophys Res Commun (2005) 333(4):1107-15. doi:10.1016/j.bbrc.2005.05.198

51. Ehrenreich H, Rieckmann P, Sinowatz F, Weih KA, Arthur LO, Goebel FD, et al. Potent stimulation of monocytic endothelin-1 production by HIV-1 glycoprotein 120. J Immunol (1993) 150(10):4601-9.

52. Takano Y, Shimokado K, Hata Y, Yoshida M. HIV envelope protein gp120triggered CD4+ T-cell adhesion to vascular endothelium is regulated via CD4 and CXCR4 receptors. Biochim Biophys Acta (2007) 1772(5):549-55. doi:10.1016/j.bbadis.2007.01.010

53. Schecter AD, Berman AB, Yi L, Mosoian A, McManus CM, Berman JW, et al. HIV envelope gp120 activates human arterial smooth muscle cells. Proc Natl Acad Sci USA (2001) 98(18):10142-7. doi:10.1073/pnas. 181328798

54. Lehmann MH, Walter S, Ylisastigui L, Striebel F, Ovod V, Geyer M, et al. Extracellular HIV-1 Nef increases migration of monocytes. Exp Cell Res (2006) 312(18):3659-68. doi:10.1016/j.yexcr.2006.08.008

55. Almodovar S, Hsue PY, Morelli J, Huang L, Flores SC, Lung HIVS. Pathogenesis of HIV-associated pulmonary hypertension: potential role of HIV-1 Nef. Proc Am Thorac Soc (2011) 8(3):308-12. doi:10.1513/pats.201006-046WR

56. Almodovar S, Knight R, Allshouse AA, Roemer S, Lozupone C, McDonald $\mathrm{D}$, et al. Human immunodeficiency virus nef signature sequences are 
associated with pulmonary hypertension. AIDS Res Hum Retroviruses (2012) 28(6):607-18. doi:10.1089/AID.2011.0021

57. Hofman FM, Wright AD, Dohadwala MM, Wong-Staal F, Walker SM. Exogenous tat protein activates human endothelial cells. Blood (1993) 82(9):2774-80.

58. Cota-Gomez A, Flores NC, Cruz C, Casullo A, Aw TY, Ichikawa H, et al. The human immunodeficiency virus-1 Tat protein activates human umbilical vein endothelial cell E-selectin expression via an NF-kappa B-dependent mechanism. J Biol Chem (2002) 277(17):14390-9. doi:10.1074/jbc.M108591200

59. Dalvi P, O’Brien-Ladner A, Dhillon NK. Downregulation of bone morphogenetic protein receptor axis during HIV-1 and cocaine-mediated pulmonary smooth muscle hyperplasia: implications for HIV-related pulmonary arterial hypertension. Arterioscler Thromb Vasc Biol (2013) 33(11):2585-95. doi:10.1161/ATVBAHA.113.302054

60. Porter KM, Walp ER, Elms SC, Raynor R, Mitchell PO, Guidot DM, et al. Human immunodeficiency virus-1 transgene expression increases pulmonary vascular resistance and exacerbates hypoxia-induced pulmonary hypertension development. Pulm Circ (2013) 3(1):58-67. doi:10.4103/2045-8932.109915

61. Parikh RV, Scherzer R, Nitta EM, Leone A, Hur S, Mistry V, et al. Increased levels of asymmetric dimethylarginine are associated with pulmonary arterial hypertension in HIV infection. AIDS (2014) 28(4):511-9. doi:10.1097/QAD. 0000000000000124

62. Ascherl G, Hohenadl C, Schatz O, Shumay E, Bogner J, Eckhart L, et al. Infection with human immunodeficiency virus-1 increases expression of vascular endothelial cell growth factor in T cells: implications for acquired immunodeficiency syndrome-associated vasculopathy. Blood (1999) 93(12):4232-41.

63. Morse JH, Barst RJ, Itescu S, Flaster ER, Sinha G, Zhang Y, et al. Primary pulmonary hypertension in HIV infection: an outcome determined by particular HLA class II alleles. Am J Respir Crit Care Med (1996) 153(4 Pt 1):1299-301. doi:10.1164/ajrccm.153.4.8616557

64. Cool CD, Rai PR, Yeager ME, Hernandez-Saavedra D, Serls AE, Bull TM, et al. Expression of human herpesvirus 8 in primary pulmonary hypertension. $N$ Engl J Med (2003) 349(12):1113-22. doi:10.1056/NEJMoa035115

65. Nicastri E, Vizza CD, Carletti F, Cicalini S, Badagliacca R, Poscia R, et al. Human herpesvirus 8 and pulmonary hypertension. Emerg Infect Dis (2005) 11(9):1480-2. doi:10.3201/eid1109.0408801480

66. Montani D, Marcelin AG, Sitbon O, Calvez V, Simonneau G, Humbert M. Human herpes virus 8 in HIV and non-HIV infected patients with pulmonary arterial hypertension in France. AIDS (2005) 19(11):1239-40. doi:10.1097/01. aids.0000176230.94226.06

67. Swain SD, Han S, Harmsen A, Shampeny K, Harmsen AG. Pulmonary hypertension can be a sequela of prior pneumocystis pneumonia. Am J Pathol (2007) 171(3):790-9. doi:10.2353/ajpath.2007.070178

68. Recusani F, Di Matteo A, Gambarin F, D’Armini A, Klersy C, Campana C. Clinical and therapeutical follow-up of HIV-associated pulmonary hypertension: prospective study of 10 patients. AIDS (2003) 17(Suppl 1):S88-95. doi:10.1097/00002030-200304001-00013

69. Dellegrottaglie S, Garcia-Alvarez A, Guarini P, Perrone-Filardi P, Fuster V, Sanz J. Prevalence and severity of ventricular dysfunction in patients with HIVrelated pulmonary arterial hypertension. Heart Lung (2014) 43(3):256-61. doi:10.1016/j.hrtlng.2014.02.007

70. Araujo I, Enjuanes-Grau C, Lopez-Guarch CJ, Narankiewicz D, Ruiz-Cano MJ, Velazquez-Martin T, et al. Pulmonary arterial hypertension related to human immunodeficiency virus infection: a case series. World J Cardiol (2014) 6(6):495-501. doi:10.4330/wjc.v6.i6.495

71. Degano B, Yaici A, Le Pavec J, Savale L, Jais X, Camara B, et al. Long-term effects of bosentan in patients with HIV-associated pulmonary arterial hypertension. Eur Respir J (2009) 33(1):92-8. doi:10.1183/09031936.00094808

72. Klings ES, Farber HW. Current management of primary pulmonary hypertension. Drugs (2001) 61(13):1945-56. doi:10.2165/00003495-200161130-00005

73. Glesby MJ, Aberg JA, Kendall MA, Fichtenbaum CJ, Hafner R, Hall S, et al. Pharmacokinetic interactions between indinavir plus ritonavir and calcium channel blockers. Clin Pharmacol Ther (2005) 78(2):143-53. doi:10.1016/j. clpt.2005.04.005

74. Aguilar RV, Farber HW. Epoprostenol (prostacyclin) therapy in HIV-associated pulmonary hypertension. Am J Respir Crit Care Med (2000) 162(5):1846-50. doi:10.1164/ajrccm.162.5.2004042

75. Stricker H, Domenighetti G, Mombelli G. Prostacyclin for HIV-associated pulmonary hypertension. Ann Intern Med (1997) 127(11):1043. doi:10.7326/ 0003-4819-127-11-199712010-00030
76. Ghofrani HA, Friese G, Discher T, Olschewski H, Schermuly RT, Weissmann $\mathrm{N}$, et al. Inhaled iloprost is a potent acute pulmonary vasodilator in HIV-related severe pulmonary hypertension. Eur Respir J (2004) 23(2):321-6. doi:10.1183/09031936.03.00057703

77. Cea-Calvo L, Escribano Subias P, Tello de Menesses R, Lazaro Salvador M, Gomez Sanchez MA, Delgado Jimenez JF, et al. [Treatment of HIVassociated pulmonary hypertension with treprostinil]. Rev Esp Cardiol (2003) 56(4):421-5. doi:10.1016/S0300-8932(03)76889-4

78. Merry C, Barry MG, Ryan M, Tjia JF, Hennessy M, Eagling VA, et al. Interaction of sildenafil and indinavir when co-administered to HIV-positive patients. AIDS (1999) 13(15):F101-7. doi:10.1097/00002030-199910220-00001

79. Muirhead GJ, Wulff MB, Fielding A, Kleinermans D, Buss N. Pharmacokinetic interactions between sildenafil and saquinavir/ritonavir. Br J Clin Pharmacol (2000) 50(2):99-107. doi:10.1046/j.1365-2125.2000.00245.x

80. Highleyman L. Protease inhibitors and sildenafil (Viagra) should not be combined. BETA (1999) 12(2):3.

81. Schumacher YO, Zdebik A, Huonker M, Kreisel W. Sildenafil in HIV-related pulmonary hypertension. AIDS (2001) 15(13):1747-8. doi:10.1097/00002030200109070-00026

82. Carlsen J, Kjeldsen K, Gerstoft J. Sildenafil as a successful treatment of otherwise fatal HIV-related pulmonary hypertension. AIDS (2002) 16(11):1568-9. doi:10.1097/00002030-200207260-00021

83. Wong AR, Rasool AH, Abidin NZ, Noor AR, Quah BS. Sildenafil as treatment for human immunodeficiency virus-related pulmonary hypertension in a child. J Paediatr Child Health (2006) 42(3):147-8. doi:10.1111/j.1440-1754. 2006.00816.x

84. Sitbon O, Gressin V, Speich R, Macdonald PS, Opravil M, Cooper DA, et al. Bosentan for the treatment of human immunodeficiency virusassociated pulmonary arterial hypertension. Am J Respir Crit Care Med (2004) 170(11):1212-7. doi:10.1164/rccm.200404-445OC

85. Barbaro G, Lucchini A, Pellicelli AM, Grisorio B, Giancaspro G, Barbarini G. Highly active antiretroviral therapy compared with HAART and bosentan in combination in patients with HIV-associated pulmonary hypertension. Heart (2006) 92(8):1164-6. doi:10.1136/hrt.2005.076794

86. Tcherakian C, Rivaud E, Zucman D, Metivier AC, Couderc LJ. Curing HIVassociated pulmonary arterial hypertension. Eur Respir J (2012) 39(4):1045-6. doi:10.1183/09031936.00138211

87. Dingemanse J, van Giersbergen PL. Clinical pharmacology of bosentan, a dual endothelin receptor antagonist. Clin Pharmacokinet (2004) 43(15):1089-115. doi:10.2165/00003088-200443150-00003

88. Sitbon O. HIV-related pulmonary arterial hypertension: clinical presentation and management. AIDS (2008) 22(Suppl 3):S55-62. doi:10.1097/01.aids 0000327517.62665.ec

89. Gary-Bobo G, Houssaini A, Amsellem V, Rideau D, Pacaud P, Perrin A, et al. Effects of HIV protease inhibitors on progression of monocrotalineand hypoxia-induced pulmonary hypertension in rats. Circulation (2010) 122(19):1937-47. doi:10.1161/CIRCULATIONAHA.110.973750

90. Opravil M, Sereni D. Natural history of HIV-associated pulmonary arterial hypertension: trends in the HAART era. AIDS (2008) 22(Suppl 3):S35-40. doi:10.1097/01.aids.0000327514.60879.47

91. Speich R, Jenni R, Opravil M, Jaccard R. Regression of HIV-associated pulmonary arterial hypertension and long-term survival during antiretroviral therapy. Swiss Med Wkly (2001) 131(45-46):663-5.

92. Wang X, Chai H, Yao Q, Chen C. Molecular mechanisms of HIV protease inhibitor-induced endothelial dysfunction. JAcquir Immune Defic Syndr (2007) 44(5):493-9. doi:10.1097/QAI.0b013e3180322542

93. Hebert VY, Crenshaw BL, Romanoff RL, Ekshyyan VP, Dugas TR. Effects of HIV drug combinations on endothelin-1 and vascular cell proliferation. Cardiovasc Toxicol (2004) 4(2):117-31. doi:10.1385/CT:4:2:117

94. Jiang B, Hebert VY, Zavecz JH, Dugas TR. Antiretrovirals induce direct endothelial dysfunction in vivo. J Acquir Immune Defic Syndr (2006) 42(4):391-5. doi:10.1097/01.qai.0000228790.40235.0c

95. Zinkernagel AS, von Overbeck J, Opravil M, Jenni R, Speich R, Mueller NJ. Long-term survival and interruption of HAART in HIV-related pulmonary hypertension. Eur J Clin Microbiol Infect Dis (2005) 24(2):153-5. doi:10.1007/s10096-005-1289-7

96. Torre D, Pugliese A. Impact of antiretroviral therapy among HIV-1-infected patients with pulmonary hypertension. Clin Infect Dis (2004) 39(10):1549-50. doi: $10.1086 / 425503$ 
97. Pugliese A, Isnardi D, Saini A, Scarabelli T, Raddino R, Torre D. Impact of highly active antiretroviral therapy in HIV-positive patients with cardiac involvement. J Infect (2000) 40(3):282-4. doi:10.1053/jinf.2000.0672

98. van Loon RL, Roofthooft MT, Hillege HL, ten Harkel AD, van Osch-Gevers M, Delhaas T, et al. Pediatric pulmonary hypertension in the Netherlands: epidemiology and characterization during the period 1991 to 2005. Circulation (2011) 124(16):1755-64. doi:10.1161/CIRCULATIONAHA.110.969584

99. Bray GL, Martin GR, Chandra R. Idiopathic pulmonary hypertension, hemophilia A, and infection with human immunodeficiency virus (HIV). Ann Intern Med (1989) 111(8):689-90. doi:10.7326/0003-4819-111-8-689_2

100. Hays MD, Wiles HB, Gillette PC. Congenital acquired immunodeficiency syndrome presenting as cor pulmonale in a 10-year-old girl. Am Heart J (1991) 121(3 Pt 1):929-31. doi:10.1016/0002-8703(91)90215-4

101. de Chadarevian JP, Lischner HW, Karmazin N, Pawel BR, Schultz TE. Pulmonary hypertension and HIV infection: new observations and review of the syndrome. Mod Pathol (1994) 7(6):685-9.

102. Ruchelli ED, Nojadera G, Rutstein RM, Rudy B. Pulmonary veno-occlusive disease. Another vascular disorder associated with human immunodeficiency virus infection? Arch Pathol Lab Med (1994) 118(6):664-6.

103. Rhodes J, Schiller MS, Montoya CH, Fikrig S. Severe pulmonary hypertension without significant pulmonary parenchymal disease in a pediatric patient with acquired immunodeficiency syndrome. Clin Pediatr (1992) 31(10):629-31. doi:10.1177/000992289203101010

104. Monfort Gil R, Asensio de la Cruz O, Gili Bigata T, Pineda Solas V, Perich Duran RM. [Pulmonary hypertension associated with vertically transmitted HIV infection in an adolescent girl]. An Pediatr (2008) 68(2):189-90. doi: $10.1157 / 13116236$

105. Feiterna-Sperling C, Huseman D, Timme J, Buhrer C, Obladen M. Resolution of human immunodeficiency virus type 1 infection-related severe pulmonary hypertension in a very low-birth-weight infant. Pediatr Infect Dis J (2008) 27(6):564-7. doi:10.1097/INF.0b013e318165f1cf

106. Pongprot Y, Sittiwangkul R, Silvilairat S, Sirisanthana V. Cardiac manifestations in HIV-infected Thai children. Ann Trop Paediatr (2004) 24(2):153-9. doi:10.1179/027249304225013439

107. Ferrand RA, Desai SR, Hopkins C, Elston CM, Copley SJ, Nathoo K, et al. Chronic lung disease in adolescents with delayed diagnosis of vertically acquired HIV infection. Clin Infect Dis (2012) 55(1):145-52. doi:10.1093/cid/ cis 271

108. Cunha Mdo C, Siqueira Filho AG, Santos SR, Abreu TF, Oliveira RH, Baptista DM, et al. AIDS in childhood: cardiac involvement with and without triple combination antiretroviral therapy. Arq Bras Cardiol (2008) 90(1):11-7. doi:10.1590/S0066-782X2008000100003

109. Pathmanand C, Anuroj K, Thisyakorn C, Sueblinvong V. Cardiovascular manifestations and left ventricular functions in human immunodeficiency virus infection in infants and children in Thailand. Southeast Asian J Trop Med Public Health (1997) 28(2):370-4.

110. Bannerman C, Chitsike I. Cor pulmonale in children with human immunodeficiency virus infection. Ann Trop Paediatr (1995) 15(2):129-34.

111. Berger RM, Beghetti M, Humpl T, Raskob GE, Ivy DD, Jing ZC, et al. Clinical features of paediatric pulmonary hypertension: a registry study. Lancet (2012) 379(9815):537-46. doi:10.1016/S0140-6736(11)61621-8
112. Barst RJ, McGoon MD, Elliott CG, Foreman AJ, Miller DP, Ivy DD. Survival in childhood pulmonary arterial hypertension: insights from the registry to evaluate early and long-term pulmonary arterial hypertension disease management. Circulation (2012) 125(1):113-22. doi:10.1161/CIRCULATIONAHA. 111.026591

113. Cheseaux JJ, Jotterand V, Aebi C, Gnehm H, Kind C, Nadal D, et al. Hyperlipidemia in HIV-infected children treated with protease inhibitors: relevance for cardiovascular diseases. J Acquir Immune Defic Syndr (2002) 30(3):288-93. doi:10.1097/00126334-200207010-00004

114. Zareba KM, Lavigne JE, Lipshultz SE. Cardiovascular effects of HAART in infants and children of HIV-infected mothers. Cardiovasc Toxicol (2004) 4(3):271-9. doi:10.1385/CT:4:3:271

115. Luginbuhl LM, Orav EJ, McIntosh K, Lipshultz SE. Cardiac morbidity and related mortality in children with HIV infection. JAMA (1993) 269(22):2869-75. doi:10.1001/jama.1993.03500220055026

116. Fisher SD, Easley KA, Orav EJ, Colan SD, Kaplan S, Starc TJ, et al. Mild dilated cardiomyopathy and increased left ventricular mass predict mortality: the prospective P2C2 HIV multicenter study. Am Heart J (2005) 150(3):439-47. doi:10.1016/j.ahj.2005.06.012

117. Lipshultz SE, Easley KA, Orav EJ, Kaplan S, Starc TJ, Bricker JT, et al. Cardiac dysfunction and mortality in HIV-infected children: the prospective P2C2 HIV multicenter study. Pediatric pulmonary and cardiac complications of vertically transmitted HIV infection (P2C2 HIV) study group. Circulation (2000) 102(13):1542-8. doi:10.1161/01.CIR.102.13.1542

118. Parent F, Bachir D, Inamo J, Lionnet F, Driss F, Loko G, et al. A hemodynamic study of pulmonary hypertension in sickle cell disease. N Engl J Med (2011) 365(1):44-53. doi:10.1056/NEJMoa1005565

119. Coghlan JG, Denton CP, Grunig E, Bonderman D, Distler O, Khanna D, et al. Evidence-based detection of pulmonary arterial hypertension in systemic sclerosis: the DETECT study. Ann Rheum Dis (2014) 73(7):1340-9. doi:10.1136/annrheumdis-2013-203301

Conflict of Interest Statement: The Review Editor Dunbar Ivy declares that, despite having collaborated on publications in the last 2 years with author Maurice Beghetti, the review process was handled objectively. The authors declare that the research was conducted in the absence of any commercial or financial relationships that could be construed as a potential conflict of interest.

Received: 17 November 2014; accepted: 19 March 2015; published online: 07 April 2015. Citation: L'Huillier AG, Posfay-Barbe KM, Pictet H and Beghetti M (2015) Pulmonary arterial hypertension among HIV-infected children: results of a national survey and review of the literature. Front. Pediatr. 3:25. doi: 10.3389/fped.2015.00025

This article was submitted to Pediatric Cardiology, a section of the journal Frontiers in Pediatrics.

Copyright (c) 2015 L'Huillier, Posfay-Barbe, Pictet and Beghetti. This is an open-access article distributed under the terms of the Creative Commons Attribution License (CC BY). The use, distribution or reproduction in other forums is permitted, provided the original author(s) or licensor are credited and that the original publication in this journal is cited, in accordance with accepted academic practice. No use, distribution or reproduction is permitted which does not comply with these terms. 